\title{
The Effects of Rosemary (Rosmarinus officinalis) Leaves Powder on Glucose Level, Lipid Profile and Lipid Perodoxation
}

\author{
Louay Labban', Usama El-Sayed Mustafa'2, Yasser Mahmoud Ibrahim² \\ ${ }^{1}$ Department of Nutrition, Faculty of Health Sciences, University of Kalamoon, Damascus, Syria \\ ${ }^{2}$ Department of Home Economics, Faculty of Specific Education, Ain Shams University, Cairo, Egypt \\ Email: drlouay@gmail.com
}

Received 17 December 2013; revised 16 January 2014; accepted 15 February 2014

Copyright (C) 2014 by authors and Scientific Research Publishing Inc.

This work is licensed under the Creative Commons Attribution International License (CC BY).

http://creativecommons.org/licenses/by/4.0/

(c) (i) Open Access

\section{Abstract}

Introduction: Various herbs have been used as treatment and prevention for several chronic diseases such as diabetes, hypercholesterolemia and triglyceridemia; one of those herbs is Rosemary, which has biological antioxidant mechanisms. Rosemary is a thorny Rhamnaceous plant which is widely distributed in Europe and South-Eastern Asia. It's used in traditional medicine for its therapeutic properties. The objective of this study was to investigate the effects of Rosemary (Rosmarinus officinalis) leaves powder on glucose level and lipid profile in human. Material and Methods: Forty eight adults' men and women participated in this study which has been carried out in the UOK University. The participants were randomly selected and divided into 3 groups. The first group was given $2 \mathrm{~g}$ /day of Rosemary leaves powder, the second group was given $5 \mathrm{~g} / \mathrm{day}$ of Rosemary leaves powder while the third group was given $10 \mathrm{~g} /$ day of Rosemary leaves powder for a period of 4 weeks. Blood samples were analyzed for glucose, lipid profile and antioxidant at the beginning and the end of the study and the results were statistically analyzed. Results: The results indicated that a significant decrease in blood glucose level in the groups given $5 \mathrm{~g}$ and $10 \mathrm{~g}$ of the herb powder was observed but the difference was more significant in the group given $10 \mathrm{~g} / \mathrm{day}$. Values for total cholesterol and triglycerides were very significantly lower in the three treated groups. LDL-C level was significantly lower in the group given $10 \mathrm{~g}$ of the herb powder, while the increased levels of HDL-C was statistically significant in the group that was given $10 \mathrm{~g} / \mathrm{day}$. With regard to lipid peroxidation, giving $10 \mathrm{~g} /$ day of Rosemary leaves powder decreased significantly MDA and GR values whereas significantly increases the values of vitamin $C$ and $\beta$ carotene. Conclusion: In conclusion Rosmarinus officinalis appears to improve not only hyperglycemia but also dyslipidemia in a dose dependent manner and decreases lipid peroxidation through increasing antioxidants levels and this will reduce the risk of chronic disease such as cardiovascular disease. 


\section{Keywords}

\section{Rosemary; Hypoglycemic; Hypolipidemic; Antioxidants}

\section{Introduction}

Medicinal plants have been used for many centuries in the management of many diseases such as Diabetes Mellitus, CVD, hypertension, and many other diseases [1]. The use of herbs as medicines has played an important role in nearly every culture, including Asia, Africa, Europe and the Americas [2]. In the traditional medicine, the use of medicinal plants is on the rise because of their treatment properties of various diseases especially diabetes and obesity [3]. Herbal medicine is based on the premise that plants contain natural substances that can promote health and alleviate illness. Several herbs can help to reduce blood sugar, high blood cholesterol, provide some protection against cancer and stimulate the immune system [4].

Rosemarinus officinalis L. an evergreen perennial aromatic shrub belonging to the family Labiatae, commonly called Rosemary, native to the north and south coasts of the Mediterranean Sea and is a common household plant [5]. Rosemary is commonly used as a spice and flavoring agent in food processing [6].

In recent past decades, an increasing evidence indicates the positive role of traditional medicinal plants in the prevention or control of some metabolic disorders like diabetes, heart diseases and certain types of cancers [7].

Rosemary composed of dried leaves and flowers constitutes a particularly interesting source of biologically active phytochemicals as it contains a variety of phenolic compounds including carnosol, carnosic acid, rosmanol, 7-methyl-epirosmanol, isorosmanol, rosmadial and caffeic acid, with substantial in vitro antioxidant activity [8] [9]. Among the herbal extracts reported to have antioxidant activity, rosemary (Rosmarinus officinalis L.) is one of the most widely commercialized plant extracts; it is used as a culinary herb for flavoring and as an antioxidant in processed foods and cosmetics [10].

The antioxidant potential of rosemary and its constituents has predominantly been derived from in vitro and in vivo studies [11]. Rosemary contains some antioxidant phenolics that have been shown to provide a defense against oxidative stress from oxidizing agents and free radicals [12]. Many herbal such as Rosemary infusions, frequently used as home medicines have antioxidative and pharmacological properties related to the presence of phenolic compounds, especially phenolic acids and flavonoids. Polyphenols are also known for their ability to prevent fatty acids from oxidative decay [13].

A wealth of studies demonstrated antioxidant, diuretic, anti-inflammatory, anti-microbial, anti-carcinogenic, hypoglycemic and hypolipidimic activities of rosemary [14]-[17].

As there is a possibility for Rosemary leaves to play a role as a hypoglycemic and a hypolipidemic agent, the present study was designed to evaluate the effects of rosemary, on blood lipid profile and blood sugar of human. Blood lipid profile includes, triglycerides, high density lipoprotein cholesterol (HDL), and low density lipoprotein (LDL).

\section{Materials and Methods}

\subsection{Subjects}

A group of 48 individuals divided into 23 men and 25 women aged between 20 to 57 years (32 \pm 13 ) participated in this study. They were divided into three groups according to the intake dosage of Rosemary leaves powder.

They were randomly given 2, 5 or 10 g/day of Rosemary leaves powder for a period of 8 weeks. The blood specimens were collected at the beginning and the end of this period in order to investigate the effect of Rosemary leaves powder on serum blood glucose, lipid parameters such as total cholesterol, triglyceride, LDL and HDL and some antioxidants markers such as Glutathione reductase (GR), total vitamin C, B-carotene and malnodialdehyde (MDA).

\subsection{Questionnaire Form}

The questionnaire was divided into two sections; the first one was for personal information such as name, age 
and sex. The second was about medical history, and contained important questions such as:

- Are you now following a special diet or taking any prescribed medication for the purpose of losing weight?

- Do you have a problem of dyslipidemia or hyperlipidemia? And what is your action related to it?

The participants were chosen based on their answers, and the exclusion process was done for each person having any kind of diet or medication at the time of the study.

\subsection{Methodology}

\subsubsection{Rosemary Powder Preparation}

The plant materials, Rosemary leaves were collected from the organic farm in Fayom city, Egypt, during November 2012.

The plant materials were washed of residual soil and dried under-vacuum drying machine as follows: temperature at $50^{\circ} \mathrm{C}$, under-vacuum of 0.3 bar and time for 3 hours, till complete drying and ground to fine powder. The fine powder of Rosemary Leaves was stored in air tight plastic containers until used.

\subsubsection{Blood Tests}

At the beginning of this study, the blood specimens were collected as following the patient was then asked to attend the next morning after an overnight fast, to avoid any dietary influence on the serum lipid or oxidation level. Upon returning, the patient was asked to sit comfortably in a dental chair in a reclining position. A tourniquet was then applied above the right cubital fossa, and the needle of a disposable 2-ml, 23-gauge syringe was inserted into the vein. About $2 \mathrm{ml}$ of venous blood was withdrawn and then transferred to a plain 10-ml glass test tube. After the blood had coagulated, the test tube containing the blood was subjected to centrifugation for about 4 - $5 \mathrm{~min}$ at $2500 \mathrm{rpm}$. The test tube was then removed from the centrifuge, and the serum layer was pipetted into a vial, which was then stored in a refrigerator under protection from light.

Serum total cholesterol (TC), triglycerides (TG) and high density lipoprotein cholesterol (HDL-c) were performed using special kits (MEDICHEM MIDDLE EAST, cat. NO. 12220).

Glutathion reductase (GR): Erythrocyte glutathione reductase was measured by ELISA kit (Cayman's Glutathion reductase assay kits, USA) (Glutathione reductase assay kit item number 723202).

Vitamin C (V.C): Plasma vitamin C concentrations estimated with a fluorometric assay by Bio-Assay system, USA kit.

Beta carotene: Plasma Beta carotene levels were estimated by the Bradley and Hornbeck method using a beta-carotene stock standard (Sigma-Aldrich Corp. St. Louis, MO, USA) [18].

Fasting blood glucose was also estimated in the plasma using the Glucose Enzokit made in Switzerland. The above procedure was repeated for all of the patients.

After ingestion different doses of Rosmary powder (2, 5 or $10 \mathrm{~g} /$ day) for 8 weeks, the procedures were repeated in order to investigate the effect of different doses of Rosemary on both lipid profile and blood glucose and lipid peroxidation and antioxidants level.

\subsection{Statistical Analysis}

In this study, t-test was conducted to see if there were any statistical differences between control and intervention groups. The data collected were entered into SPSS (10) program and significance difference was set at $\mathrm{P}<$ 0.01 and $\mathrm{P}<0.05$.

\section{Results}

\subsection{The Effect of Rosemary Powder on Fasting Blood Glucose}

DM is a group of metabolic disorders that share the common feature of hyperglycemia. It is worth mentioning that several reports have suggested the possible use of Rosemary extracts in the reduction of blood glucose and lipid profile [16].

The current data showed that treatment with all doses (2, 5 and $10 \mathrm{~g} /$ day) of Rosemary leaves powder produced significant reduction in glucose level for all participants. The highest dose of $10 \mathrm{~g}$ /day tended to produce the highest reduction of glucose by $18.25 \%$ while the dose of 5 g produced reduction in glucose level only by $15.74 \%$ and 2 g/day reduced glucose level by $11.2 \%$ as shown in Table 1 . It should be notated that, treating 
Table 1. The effect of different doses of Rosmary powder (R. officnalis) on fasting serum glucose (mg/dL).

\begin{tabular}{ccccc}
\hline Dose (g/day) & Treatment & Fasting glucose $(\mathbf{m g} / \mathbf{d L})$ & P-value & \% reduction \\
\hline 2 & Before & $125 \pm 16$ & 0.25 & 11.2 \\
& After & $111 \pm 13$ & & 15.74 \\
5 & Before & $127 \pm 13$ & $0.001^{* *}$ & 18.25 \\
\hline
\end{tabular}

*** significant at $\mathrm{P}<0.01$.

group with 2 g/day of Rosmary powder for 8 weeks caused no significant decreasing in fasting blood glucose. On contrast, treating groups with 5 and 10 /day of Rosmary powder for 8 weeks caused significant decreasing in fasting blood glucose.

A possible mechanism of the hypoglycemic action of $R$. officnalis was suggested to be through increasing the insulin level [19]. Moreover, recent study reported that Rosemary leads to regeneration of the $\beta$-cells of the pancreas and potentiating of insulin secretion from surviving $\beta$ cells, which indicates that Rosemary decrease blood glucose level by stimulating insulin secretion from the remnant $\beta$ cells or regenerated $\beta$ cells. [20].

Also the reduction of fasting blood glucose may be due to Rosemary might inhibit the intestinal absorption of glucose by inhibition of intestinal a-amylase enzyme [21] or a-glucosidase enzyme [22].

In addition, the remarkable antidiabetogenic effects of $R$. officnalis could be due to its potent antioxidant properties. It also might be producing its hypoglycemic activity by a mechanism independent from insulin secretion e.g. Inhibition of protein glycation, and the inhibition of endogenous glucose production [23].

\subsection{The Effect of Rosemary Powder on Blood Lipid Profile}

Obesity is a condition in which excess body fat has accumulated to such an extent that health maybe negatively affected. There is an increasing tendency by patients with hyperlipidemia to use the natural products to overcome the toxicity of synthetic drugs. So the purpose of this work was to investigate the possible hypolipidemic activity of Rosemary ( $R$. officnalis).

This study has showed that treatment with all doses (2, 5 and $10 \mathrm{~g} /$ day) of Rosemary leaves powder produced significant reduction in total cholesterol (TC) level for all participants. The highest dose of $10 \mathrm{~g} /$ day tended to produce the highest reduction of TC by $34.48 \%$ followed by $5 \mathrm{~g} /$ day with reduction $17.97 \%$ and $2 \mathrm{~g} /$ day 11.48 (Table 2). This reduction could be of clinical importance as it normalized TC values because TC value of more than $200 \mathrm{mg} / \mathrm{dL}$ could be linked to increased risk of heart and blood vessel diseases [20].

The present data are in accordance with those of Hanan and Al-Nahdi. (2012) study that showed significant reduction in total cholesterol level for Streptozotocin-induced diabetic rats rats given $200 \mathrm{mg} / \mathrm{kg} / \mathrm{d}$ of Rosemary extract for a period of 3 weeks.

Hypercholesterolemia or more specifically elevated plasma LDL-cholesterol is an important risk factor for development and progression of atherosclerosis [24] which is accompanied by the production of free radicals which initiate processes involved in atherogenesis [25].

$R$. officnalis administration was found to normalize LDL-C level for the three treatment groups. It's worth mentioning that, the dose of $10 \mathrm{~g}$ had the highest effect with reduction came up to $34.28 \%$. While, treatment with 2 and $5 \mathrm{~g}$ reduced LDL-C level by 15.58\% and 28.46\%, respectively as demonstrated in Table 3 . Additionally, considering the goal value of LDL-C is less than $110 \mathrm{mg} / \mathrm{dL}$ [26], the improvement noticed after administration of $R$. ofiicnalis leaves cannot be ignored for groups treated with 5 and $10 \mathrm{~g} / \mathrm{day}$. On contrast group fed on $2 \mathrm{~g} /$ day of rosemary powder tended to gave LDL-c higher than safety recommendation limit (less than $110 \mathrm{mg} / \mathrm{dL})$.

The reduction of TC and LDL-C by both doses of $R$. officnalis may be due to the inhibition of pancreatic lipase and hormone sensitive lipase by a variety of constituents in the extract especially rosmarinic acid and other phenolics that may each contribute individually to the inhibition of pancreatic lipase (PL) and hormone sensitive lipase (HSL) in dose dependent manner with potency lower than orlistat, the only FDA approved PL inhibitor in 
Table 2. The effect of different doses of Rosmary powder (R. officnalis) on serum lipid profile.

\begin{tabular}{|c|c|c|c|c|c|c|c|c|c|}
\hline \multirow{2}{*}{$\begin{array}{l}\text { Dose } \\
\text { (g/day) }\end{array}$} & \multirow{2}{*}{ Treatment } & \multicolumn{2}{|c|}{ TC } & \multicolumn{2}{|c|}{ LDL-C } & \multicolumn{2}{|c|}{ HDL-C } & \multicolumn{2}{|c|}{ TAG } \\
\hline & & (mg/dL) & $\begin{array}{c}\text { P-value/ } \\
\text { \% reduction }\end{array}$ & $(\mathrm{mg} / \mathrm{dL})$ & $\begin{array}{c}\text { P-value/ } \\
\text { \% reduction }\end{array}$ & (mg/dL) & $\begin{array}{c}\text { P-value/ } \\
\text { \% reduction }\end{array}$ & (mg/dL) & $\begin{array}{c}\text { P-value/ } \\
\% \text { reduction }\end{array}$ \\
\hline \multirow{2}{*}{2} & Before & $235 \pm 65$ & \multirow{2}{*}{$\begin{array}{c}0.0216^{*} \\
11.48\end{array}$} & $154 \pm 62$ & \multirow{2}{*}{$\begin{array}{l}0.104 \\
15.58\end{array}$} & $44 \pm 6$ & \multirow{2}{*}{$\begin{array}{c}0.4777 \\
4.54\end{array}$} & $187 \pm 28$ & \multirow{2}{*}{$\begin{array}{c}0.0046^{* *} \\
14.97\end{array}$} \\
\hline & After & $208 \pm 42$ & & $130 \pm 46$ & & $46 \pm 5$ & & $159 \pm 17$ & \\
\hline \multirow{2}{*}{5} & Before & $217 \pm 23$ & \multirow{2}{*}{$\begin{array}{c}0.0016^{* *} \\
17.97\end{array}$} & $137 \pm 17$ & \multirow{2}{*}{$\begin{array}{c}0.0066^{* *} \\
28.46\end{array}$} & $46 \pm 6$ & \multirow{2}{*}{$\begin{array}{c}0.0937 \\
15.21\end{array}$} & $169 \pm 21$ & \multirow{2}{*}{$\begin{array}{c}0.0040^{* *} \\
21.3\end{array}$} \\
\hline & After & $178 \pm 15$ & & $98 \pm 18$ & & $53 \pm 5$ & & $133 \pm 32$ & \\
\hline \multirow{2}{*}{10} & Before & $232 \pm 25$ & \multirow{2}{*}{$\begin{array}{c}0.0002^{* *} \\
34.48\end{array}$} & $140 \pm 20$ & \multirow{2}{*}{$\begin{array}{c}0.0029^{* *} \\
34.28\end{array}$} & $48 \pm 4$ & \multirow{2}{*}{$\begin{array}{l}0.023^{*} \\
22.91\end{array}$} & $172 \pm 22$ & \multirow{2}{*}{$\begin{array}{c}0.0021^{* *} \\
29.06\end{array}$} \\
\hline & After & $152 \pm 18$ & & $92 \pm 16$ & & $59 \pm 6$ & & $122 \pm 41$ & \\
\hline
\end{tabular}

(TC) total cholesterol, (LDL-C) low density lipoprotein cholesterol, (HDL-C) high density lipoprotein cholesterol, (TAG) triglycerides (mg/dL). "Significant at $\mathrm{P}<0.05,{ }^{* *}$ significant at $\mathrm{P}<0.01$.

Table 3. The effect of different doses of $R$. officnalis on lipid peroxidation product and antioxidant.

\begin{tabular}{|c|c|c|c|c|c|c|c|c|}
\hline \multirow{2}{*}{ Treatment } & \multicolumn{2}{|c|}{ GR } & \multicolumn{2}{|c|}{ Vitamin. C } & \multicolumn{2}{|c|}{$\beta$ carotene } & \multicolumn{2}{|c|}{ MDA } \\
\hline & $\left(\mathrm{U} / \mathrm{g} \cdot \mathrm{Hb}^{-1}\right)$ & $\begin{array}{l}\text { P-value \% } \\
\text { reduction }\end{array}$ & $(\mu \mathrm{m} / \mathrm{l})$ & $\begin{array}{c}\text { P-value } \\
\% \text { increase }\end{array}$ & $(\mu \mathrm{m} / \mathrm{l})$ & $\begin{array}{l}\text { P-value \% } \\
\text { increase }\end{array}$ & (n mol/g Hb ) & $\begin{array}{l}\text { P-value \% } \\
\text { reduction }\end{array}$ \\
\hline Before & $3.13 \pm 0.2$ & \multirow{2}{*}{$\begin{array}{c}0.705 \\
0.95\end{array}$} & $40.2 \pm 3.6$ & \multirow{2}{*}{$\begin{array}{c}0.323 \\
8\end{array}$} & $0.4 \pm 0.01$ & \multirow{2}{*}{$\begin{array}{c}0.225 \\
7.5\end{array}$} & $13 \pm 1.2$ & \multirow{2}{*}{$\begin{array}{c}0.036^{*} \\
13.6\end{array}$} \\
\hline After & $3.10 \pm 0.3$ & & $43 \pm 2.9$ & & $0.43 \pm 0.005$ & & $8.1 \pm 1.4$ & \\
\hline Before & $3.21 \pm 0.4$ & \multirow{2}{*}{$\begin{array}{c}0.226 \\
6.73\end{array}$} & $42.2 \pm 2.3$ & 0.225 & $0.39 \pm 0.07$ & \multirow{2}{*}{$\begin{array}{l}0.056^{*} \\
33.33\end{array}$} & $7.08 \pm 1.4$ & \multirow{2}{*}{$\begin{array}{l}0.024^{*} \\
12.43\end{array}$} \\
\hline After & $3.0 \pm 0.3$ & & $47 \pm 3.3$ & 11.37 & $0.52 \pm 0.005$ & & $6.2 \pm 1.9$ & \\
\hline Before & $3.19 \pm 0.3$ & \multirow{2}{*}{$\begin{array}{c}0.002^{* *} \\
15.36\end{array}$} & $41.2 \pm 3.8$ & $0.043^{*}$ & $0.42 \pm 0.01$ & \multirow{2}{*}{$\begin{array}{c}0.017^{* *} \\
45.23\end{array}$} & $7.18 \pm 1.5$ & \multirow{2}{*}{$\begin{array}{c}0.004^{* *} \\
36.21\end{array}$} \\
\hline After & $2.7 \pm 0.06$ & & $49 \pm 4.0$ & 18.93 & $0.61 \pm 0.006$ & & $5.2 \pm 1.2$ & \\
\hline
\end{tabular}

(GR) Glutathione reductase, (MDA) malnodialdehyde, ${ }^{*}$ Significant at $\mathrm{P}<0.05$, ${ }^{* *}$ significant at $\mathrm{P}<0.001$.

the market [27] [28]. Also found that the rosemary extract has been targeting the hormone sensitive lipase (HSL) which has been extensively studied for its effects on the metabolic switch between glucose and free fatty acids (FFAs) as an energy source. Moreover, the reduction of TC and LDL-C may be attributed to the presence of saponins that form insoluble complex with cholesterol and increase fecal lipid excretion, they also increase the liver LDL-C receptor activity [29]. Furthermore, another study revealed that glycemic control following administration of $R$. officnalis extract was associated with its hypolipidemic effect as elevated serum insulin level increased the clearance rate of both very low density lipoprotein cholesterol (VLDL-C) and LDL-C subsequently [30].

The reduction in lipid levels observed after the consumption of Rosemary has been suggested in other studies to be caused by a reduction in the absorption of dietary fat supported by an increase in fecal fat excretion [31]. Also, the possibility that rosemary decreased LDL-C production and oxidation, changed LDL receptor activity and uptake of LDL-C by hepatocytes cannot be excluded [32].

As demonstrated in (Table 2), there was an increase in HDL-C level, but the statistical difference was more significant in the $10 \mathrm{~g} /$ day group. The improvement in HDL-C level came up to $15.58 \%$, 28.46\% and 34.28\% after consumption of $2 \mathrm{~g}, 5 \mathrm{~g}$ and $10 \mathrm{~g}$ /day of Rosemary, respectively. This finding is similar to that of (Hanan and Alnahdi. 2012) which also showed an increase in HDL-C level in Streptozotocin-induced diabetic rats after administration of $200 \mathrm{mg} / \mathrm{kg}$ of Rosemary extract for 21 days. It is also in accordance with another study conducted by [33] (Alaa et al., 2010) which showed an increase in HDL-C in experimental rats after administration of Rosemary powder at $2.5 \%$ (wt/wt) of the standard diet for the Rosemary powder group and Rosemary extract at a rate of $0.5 \%(\mathrm{wt} / \mathrm{wt})$ in the Rosemary extract group.

Possible explanation was due to glucose metabolism improvement as this direct protein metabolism into anabolic instead of catabolic process, which results in synthesis of proteins such as apolipoprotein A1 (Apo-A1) 
that constitute 70\% of HDL-C structure which, in turn, results in increase of HDL-C concentration [4].

The effect of different doses of $R$. officnalis on serum TAG was illustrated in (Table 2). The reduction in TAG was estimated to be $15 \%$ for participants consumed $2 \mathrm{~g}$ of the leaves powder daily compared to $21 \%$ for those who consumed $5 \mathrm{~g}$. Also it's important to spot light that the TAG value of $\leq 150 \mathrm{mg} / \mathrm{dL}$ is the normal value in healthy individuals [26]. It may be also stated that the rosemary leaves leads to regeneration of the $\beta$-cells of the pancreas and potentiating of insulin secretion from surviving $\beta$ cells. The increase in insulin secretion and consequent decrease in blood glucose level may lead to control of lipolytic hormones. A number of other plants have also been reported to have insulin stimulatory along with antihyperlipidemic effects [25]. It is probably that rosemary leaf changed the rate of fatty acids oxidation in the liver and reduced the rate of triglycerides biosynthesis [32].

\subsection{The Effect of Rosemary Powder on Blood Lipid Peroxidation Product and Antioxidant}

With regard to lipid peroxidation and antioxidants level, this study found that Rosemary decreased GR at all intake levels. The reduction percentage in GR was $0.95 \%$ at $2 \mathrm{~g} /$ day and $6.73 \%$ and $15.36 \%$ at $5 \mathrm{~g} / \mathrm{day}$ and 10 $\mathrm{g} /$ day, respectively. There was a significant statistical difference for group treated with $10 \mathrm{~g} / \mathrm{day}(\mathrm{p}=0.002)$ as shown in Table 3. Also this table showed the effect of Rosemary intake on Vitamin C levels. This product improved the levels of vitamin $C$ and the percentage of the increase was $8 \%$ at $2 \mathrm{~g} /$ day to $11.37 \%$ at $5 \mathrm{~g} /$ day and $19.93 \%$ at $10 \mathrm{~g} /$ day which had significant difference at this level. $\beta$ carotene levels have been improved with increased intake levels, this increase estimated at $7.5 \%$ at $2 \mathrm{~g} /$ day and $33.33 \%$ and 45.23 at 5/g day and $10 \mathrm{~g} /$ day, respectively.

This study has also shown that intake of Rosemary reduces MDA levels. The percentage of this reduction was $13.6 \%$ at $2 \mathrm{~g} /$ day and at $5 \mathrm{~g} /$ day it was $12.43 \%$ whereas it was decreased to 36.21 at $10 \mathrm{~g}$ /day which had very significant difference at this level. These findings are shown in Table 3.

Free radical damage including hydroperoxides, singlet oxygen, and hydrogen peroxides, evaluated by MDA levels as the final products of lipid peroxidation, and the direct depletion of antioxidant reserves [34]. The results indicated that, all treated groups tended to have MDA lower than non-treated groups, even there were significant difference were observed between them. The decrease in the MDA level, by Rosemary leaves powder may be attributed to the antioxidant properties that inhibited lipid peroxidation, this in turn stabilize the reactive radicals, preserve the cellular [35]. The current results were agreed with the previous study which reported that Rosemary extract significantly decrease malonaldehyde (MDA) contents, the crude extract also acted as a cytoprotective agent when reflected a Free radical-scavenging activity that elicited widespread damage to cell constituents such as membrane lipids and significantly increased the normal cells viability and the antioxidant enzymes activity superoxide dismutase (SOD) and Glutathione reductase (GR) [36].

\section{Conclusion}

In conclusion, the results suggest that phenolic compounds from Rosmarinus officinalis protect against hyperglycemia and hypercholesterolemia-induced oxidative stress, increasing the activities of antioxidant enzymes. Moreover, rosemary leaves powder has antioxidant properties and has a positive effect on Glutathione reductase, malnodialdehyde, vitamin C content and B-carotene. Supplementation with these natural extracts may prove valuable in limiting the pathophysiology of numerous disorders associated with oxidative damage and inflammation. The rosemary leaves powder was also able to improve the serum lipid profile, contributing to cardiovascular disease reduction. Both doses ( 2 and $5 \mathrm{~g}$ /day) of $R$. officnalis leaves powder were found to have therapeutic potential. They possess hypolipidemic, hypoglycemic and antioxidant properties but the higher dose of $10 \mathrm{~g} /$ day was more efficient.

\section{References}

[1] El-Hilaly, J., Adil, T., Zafar, H.I. and Badiâa, L.A. (2007) Hypoglycemic, Hypocholesterolemic and Hypotriglyceridemic Effects of Continuous Intravenous Infusion of a Lyophilized Aqueous Extract of Ajuga iva l. Schreber Whole Plant in Streptozotocin-Induced Diabetic Rats. Pakistan Journal of Pharmaceutical Sciences, 20, 261-268.

[2] Wargovich, M.J., Woods, C., Hollis, D.M. and Zander, M.E. (2001) Herbals, Cancer Prevention and Health. Journal of Nutrition, 131, 3034S-3036S.

[3] Hussain, Z., Waheed, A. and Qureshi, R. et al. (2004) The Effect of Medical Plant's on Islamabad and Murree Rejoin 
of Pakistanon Insulin Secretion from INS-1 Cell's. Journal of Phytotherapy Research, 18, 73-77. http://dx.doi.org/10.1002/ptr.1372

[4] Abdul-Rahim, Al. and Taha, A. (2011) Effects of Rosemary (Rosmarinus officinalis) on Lipid Profile of Diabetic Rats. Jordan Journal of Biological Sciences, 4, 199-204.

[5] Al-Sereiti, M.R., Abu-Amer, K.M. and Sen, P. (1999) Pharmacology of Rosemary (Rosmarinus officinalis Linn.) and Its Therapeutic Potentials. Indian Journal of Experimental Biology, 37, 124-130.

[6] Saito, Y., Shiga, A., Yoshida, Y., Furuhashi, T., Fujita, Y. and Niki, E. (2004) Effects of Novel Gaseous Antioxidative System Containing a Rosemary Extract on the Oxidation Induced by Nitrogen Dioxide and Ultraviolet Radiation. Bioscience, Biotechnology, and Biochemistry, 68, 781-786. http://dx.doi.org/10.1271/bbb.68.781

[7] Zhang, X. (1996) Traditional Medicine and WHO World Health. The Magazine of World Health Organization, 2, 4-5.

[8] El Deeb, K.S. (1993) Investigation of Tannin in Some Labiatae Species. Bulletin of Faculty of Pharmacy, 31, $237-241$.

[9] Herrero, M., Plaza, M., Cifuentes, A. and Ibanez, E. (2010) Green Processes for the Extraction of Bioactives from Rosemary: Chemical and Functional Characterization via Ultra-Performance Liquid Chromatography-Tandem Mass Spectrometry and in-Vitro Assays. Journal of Chromatography, 1217, 2512-2520. http://dx.doi.org/10.1016/j.chroma.2009.11.032

[10] Zheng, W. and Wang, S.Y. (2001) Antioxidant Activity and Phenolic Compounds in Selected Herbs. Journal of Agricultural and Food Chemistry, 49, 5165-5170. http://dx.doi.org/10.1021/jf010697n

[11] Saber, A.S. and Hawazen, A.L. (2012) Protective Effect of Rosemary (Rosmarinus officinalis) Leaves Extract on Carbon Tetrachloride-Induced Nephrotoxicity in Albino Rats. Life Science Journal, 9, 779-785.

[12] Matkowski, A. (2006) Plant Phenolic Metabolites as Antioxidants and Antimutagens. In: Blume, Y., Smertenko, P. and Durzan, D.J., Eds., UV Radiation, Nitric Oxide and Cell Death in Plants. NATO Life Science Monographs, Vol. 376, IOS Press, Amsterdam, 129-148.

[13] Fecka, I., Raj, D. and Krauze-Baranowska, M. (2007) Quantitative Determination of Four Water-Soluble Compounds in Herbal Drug from Lamiaceae Using Different Chromatographic Techniques. Chromatographia, 66, 87-93. http://dx.doi.org/10.1365/s10337-007-0233-7

[14] Dearlove, R.P., Greenspan, P., Hartle, D.K., Swanson, R.B. and Hargrove, J.L. (2008) Inhibition of Protein Glycation by Extracts of Culinary Herbs and Spices. Journal of Medicinal Food, 11, 275-281. http://dx.doi.org/10.1089/jmf.2007.536

[15] Gutierrrez, R., Alvarado, J.L., Presno, M., Perez-Veyna, O., Serrano, C.J. and Yahuaca, P. (2010) Oxidative Stress Modulation by Rosmarinus officinalis in CCl4-Induced Liver Cirrhosis. Phytotherapy Research, 24, 595-601.

[16] Harach, T., Aprikian, O., Monnard, I., Moulin, J., Membrez, M., Beolor, J.-C., Raab, T., Mace, K. and Darimont, C. (2010) Rosemary (Rosmarinus officinalis L.) Leaf Extract Limits Weight Gain and Liver Steatosis in Mice Fed a High-Fat Diet. Planta Medica, 76, 566-571. http://dx.doi.org/10.1055/s-0029-1240612

[17] Nabekura, T., Yamaki, T., Hiroi, T., Ueno, K. and Kitagawa, S. (2010) Inhibition of Anticancer Drug Efflux Transporter P-Glycoprotein by Rosemary Phytochemicals. Pharmacological Research, 61, 259-263. http://dx.doi.org/10.1016/j.phrs.2009.11.010

[18] Ashish, A., Arvind, S., Vaishali, K. and Anjana, B. (2011) Estimation of Serum Beta Carotene Levels in Patients with Oral Submucous Fibrosis in India. Journal of Oral Science, 53, 427-431. http://dx.doi.org/10.2334/josnusd.53.427

[19] Vanithadevi, B. and Anuradha, C.V. (2008) Effect of Rosmarinic Acid on Insulin Sensitivity, Glyoxalase System and Oxidative Events in Liver of Fructose-Fed Mice. International Journal of Diabetes and Metabolism, 16, 35-44.

[20] Alnahdi, H.S. (2012) Effect of Rosmarinus officinalis Extract on Some Cardiac Enzymes of Streptozotocin-Induced Diabetic Rats. Journal of Health Sciences, 2, 33-37. http://dx.doi.org/10.5923/j.health.20120204.03

[21] McCue, P.P. and Shetty, K. (2004) Inhibitory Effects of Rosmarinic Acid Extracts on Porcine Pancreatic Amylase in Vitro. Asia Pacific Journal, 13, 101-106.

[22] Koga, K., Shibata, H., Yoshino, K. and Nomoto, K. (2006) Effects of 50\% Ethanol Extract from Rosemary on AlphaGlucosidase Inhibitory Activity and the Elevation of Plasma Glucose Level in Rats, and Its Active Compound. Journal of Food Science, 2, 179-218.

[23] Bakirel, T., Bakirel, U., Keles, O.U., Ulgen, S.G. and Yardibi, H. (2008) In Vivo Assessment of Antidiabetic and Antioxidant Activities of Rosemary (Rosmarinus officinalis) in Alloxan-Diabetic Rabbits. Journal of Ethnopharmacology, 116, 64-73. http://dx.doi.org/10.1016/j.jep.2007.10.039

[24] Harnafi, H., Bouanani, N.H., Aziz, M., Caid, H.S., Ghalim, N. and Amrani, S. (2007) The Hypolipidaemic Activity of Aqueous Erica Multiflora Flowers Extract in Triton WR-1339 Induced Hyperlipidaemic Rats: A Comparison with Fenofibrate. Journal of Ethnopharmacology, 109, 156-160. http://dx.doi.org/10.1016/j.jep.2006.09.017

[25] Iweala, E.J. and Oludare, F.D. (2011) Hypoglycemic Effect, Biochemical and Histological Changes of Spondias Mom- 
bin Linn, and Painari Polyandra Benth. Seeds Ethanolic Extracts in Alloxan Induced Diabetic Rats. Journal of Pharmacology and Toxicology, 6, 101-112.

[26] Fletcher, et al. (2005) Managing Abnormal Blood Lipids: A Collaborative Approach. Journal of Circulation, 112, 3184-3209. http://dx.doi.org/10.1161/CIRCULATIONAHA.105.169180

[27] Fawzi, M.A., Nizar, A., Lina, S., Rehan, B.H. and Dalal, S.A. (2012) The Effect of Rosemary (Rosmarinus officinalis. L) Plant Extracts on the Immune Response and Lipid Profile in Mice. Journal of Biology and Life Science, 3.

[28] Melzig, M.F. and Funki, I. (2007) Inhibitors of Alpha-Amylase from Plants—A Possibility to Treat Diabetes Mellitus Type 2 by Phytotherapy? Wiener Medizinische Wochenschrift, 157, 320-324.

[29] Yugarani, T., Tan, B., The, M. and Das, N. (1992) Effects of Polyphenolic Natural Products on the Lipid Profiles of Rats Fed High Fat Diets. Journal of Lipids, 27, 181-186. http://dx.doi.org/10.1007/BF02536175

[30] Newairy, A., Mansour, H., Yousef, M. and Sheweita, S. (2002) Alterations of Lipid Profile in Plasma and Liver of Diabetic Rats: Effect of Hypoglycemic Herbs. Journal of Environmental Science and Health, 37, 475-484. http://dx.doi.org/10.1081/PFC-120014877

[31] Ibarra, A., Cases, J., Roller, M., Chiralt-Boix, A., Coussaert, A., et al. (2011) Carnosic Acid-Rich Rosemary (Rosmarinus officinalis L.) Leaf Extract Limits Weight Gain Andimproves Cholesterol Levels and Glycaemia in Mice on a High-Fat Diet. British Journal of Nutrition, 106, 1182-1189. http://dx.doi.org/10.1017/S0007114511001620

[32] Attar, A.M. (2006) Comparative Physiological Study on the Effect of Rosemary, Tarragon and Bay Leaves Extract on Serum Lipid Profile of Quail, Coturnix coturnix. Saudi Journal of Biological Sciences, 13, 91-98.

[33] Alaa, I., Mohammad, M., Mohammad, H., Khaled, T., Hatim, A., Ihab, A. and Bashar, Al (2010) Inhibition of Hormone Sensitive Lipase and Pancreatic Lipase by Rosmarinus officinalis Extract and Selected Phenolic Constituent. Journal of Medicinal Plants, 4, 2235-2242.

[34] Newairy, A.S. and Abdou, H.M. (2009) Protective Role of Flax Lignans against Lead Acetate Induced Oxidative Damage and Hyperlipidemia in Rats. Food and Chemical Toxicology, 47, 813-818. http://dx.doi.org/10.1016/j.fct.2009.01.012

[35] El Kader, M.A.A., El-Sammad, N.M. and Hamdy, T. (2012) The Protective Role of Rosemary (Rosmarinus officinalis) in Lead Acetate Induced Toxicity in Rats. Journal of Applied Sciences Research, 8, 3071-3082.

[36] Osama, K.A., Gaber, M.G.S. and Romeilah, R.M. (2009) Effects of Rosmarinus officinalis Extract on Induced Nitric Oxide and Stimulated ProinXammatory Mediators Via-Bacterial Lipopolysaccharide (LPS). Australian Journal of Basic and Applied Sciences, 3, 1223-1233. 